\title{
HUBUNGAN PENGUNGKAPAN KEBERLANJUTAN DAN NILAI PERUSAHAAN : KASUS PERUSAHAAN SUB SEKTOR PERBANKAN DI INDONESIA
}

\author{
Muhammad Abdul Izzatur Rahman'); Zico Karya Saputra Domas ${ }^{2)}$; Amrie Firmansyah ${ }^{\text {3)* }}$ \\ 1) rahman.alfarid@gmail.com, Politeknik Keuangan Negara STAN \\ 2) zicoksd@gmail.com, Politeknik Keuangan Negara STAN \\ 3) amrie@pknstan.ac.id, Politeknik Keuangan Negara STAN \\ *penulis korespondensi
}

\begin{abstract}
This study aims to examine the effect of sustainability disclosure and operating cash flow on the value of banking firms. This research data employs banking sub-sector companies listed on the IDX in the form of financial reports, sustainability reports and stock prices for 2018 and 2019 obtained from www.idx.co.id, www.finance.yahoo.com, and the company's official website. Based on purposive sampling, the sample of this study amounted to 60 observations. Hypothesis testing is done by using panel data regression analysis. This study concludes that research shows that the role of sustainability disclosure has a positive effect on firm value while operating cash flow has no effect on firm value. This research indicates that the Indonesian Financial Services Authority still needs to improve policies and supervision of the implementation of sustainability carried out by companies in the banking sub-sector in Indonesia.
\end{abstract}

Keywords: banking, social responsibility, GRI 2018, market response

\begin{abstract}
Abstrak
Penelitian bertujuan untuk menguji pengaruh pengungkapan keberlanjutan dan arus kas operasi terhadap nilai perusahaan perbankan. Data penelitian ini menggunakan perusahaan sub sektor perbankan yang terdaftar di BEI berupa laporan keuangan, laporan keberlanjutan dan harga saham tahun 2018 dan 2019 yang diperoleh dari www.idx.co.id, www.finance.yahoo.com, dan situs resmi perusahaan. Berdasarkan purposive sampling, sampel penelitian ini berjumlah 60 observasi. Pengujian hipotesis dilakukan dengan menggunakan analisis regresi data panel. Penelitian ini menyimpulkan bahwa penelitian menunjukan bahwa peran pengungkapan keberlanjutan berpengaruh positif terhadap nilai perusahaan, sedangkan arus kas operasi tidak berpengaruh terhadap nilai perusahaan. Penelitian ini mengindikasikan bahwa Otoritas Jasa Keuangan tetap perlu meningkatkan kebijakan dan pengawasan penerapan keberlanjutan yang dilakukan oleh perusahaan sub sektor perbankan di Indonesia.
\end{abstract}

Kata Kunci : perbankan, tanggung jawab sosial, GRI 2018, respon pasar

\section{PENDAHULUAN}

Setiap perusahaan pada dasarnya memiliki tujuan untuk meningkatkan kinerja seoptimal mungkin demi menjamin keberlangsungan perusahaan di masa mendatang (Kieso et al., 2018). Kinerja perusahaan yang baik dapat meningkatkan keyakinan investor dalam berinvestasi di perusahaan tersebut. Akibatnya, reaksi investor yang positif dapat tercermin dari nilai perusahaan (Firmansyah, Jadi, \& Sukarno, 2021). Nilai perusahaan dapat mencerminkan kualitas dari perusahaan tersebut dan hal tersebut sangat diperhatikan oleh para pemegang saham selaku pemilik perusahaan. Nilai pasar dari suatu perusahaan ditentukan dari pergerakan nilai pasar saham yang ada di bursa saham masing-masing negara (Firmansyah, Febrian, et al., 2021). Manajemen perusahaan akan berusaha memberi sinyal terhadap stakeholder yang berkepentingan, dimana salah satunya mereka berusaha memberikan informasi yang dapat digunakan oleh investor untuk membantu dalam mengambil keputusan (Spence, 1973). Setiap perusahaan yang berkualitas akan memberikan sinyal pembeda yang memadai kepada pasar sehingga investor mampu menilai kriteria perusahaan yang layak untuk diberikan suntikan dana investasi. Penilaian investor terkait nilai pasar dari perusahaan juga dapat dilakukan dengan berbagai cara dan sudut pandang, salah satunya adalah penilaian dari publikasi laporan oleh perusahaan berisi informasi keuangan dan non-keuangan terkait kinerja perusahaan.

Indonesia merupakan salah satu negara dengan pangsa pasar yang sangat luas (Kemenperin, 2020), di mana terdapat banyak perusahaan dengan berbagai sektor yang tumbuh 


\section{JURNALKU}

Volume 1 No. 4, Desember 2021

berkembang di negara ini. Adanya sumber daya alam yang sangat melimpah, mengakibatkan Indonesia sangat menarik bagi para investor terutama dari luar negara Indonesia atau investor asing (Investindo, n.d.). Investor cenderung akan menanamkan investasinya pada perusahaan di sektor yang berkembang dan menunjukan kinerja yang baik, dan salah satu sektor industri perusahaan di Indonesia yang menunjukan hal tersebut adalah sektor perbankan. Faktor utama sektor perbankan menjadi salah satu sektor dengan profit yang tinggi karena margin bunga bersih di Indonesia yang tinggi, potensi pertumbuhan lebih jauh karena penetrasi perbankan masih berada di bawah 50\% (Katadata, 2017), serta menjadi pasar yang menjanjikan bagi perbankan syariah dengan pertumbuhan rata-rata sebesar $40 \%$ dalam beberapa tahun terakhir. Informasi kinerja perusahaan menjadi informasi yang berguna bagi investor dalam melakukan analisis dalam keputusan investasinya. Respon investor yang positif atas kinerja perusahaan dapat meningkatkan harga saham perusahaan di pasar modal, sehingga nilai perusahaan menjadi meningkat. Investor memiliki keyakinan terhadap pengelolaan perusahaan yang dilakukan dengan baik.

Kinerja pasar sektor perbankan merupakan salah satu yang menarik perhatian investor, sehingga nilai perusahaan sektor perbankan merupakan salah satu indikasi kinerja pasar modal secara umum. Sektor perbankan merupakan salah satu sektor yang penting dalam perekonomian dalam salah satu negara berkembang (Firmansyah, Sihombing, et al., 2020). Oleh karena itu, nilai perusahaan sektor perbankan dapat menjadi salah satu indikator kinerja dari sektor perbankan. Tingkat perekonomian di negara berkembang dapat dilihat dari kinerja pasar perusahaan sektor perbankan. Selain itu, faktor internal perusahaan juga menentukan kineja pasar perusahaan khususnya kebijakan yang diambil oleh manajer untuk diterapkan oleh perusahaan. Informasi atas kebijakan tersebut dapat disajikan oleh perusahaan dalam laporan keuangan dan laporan tahunan. Informasi tersebut dapat merupakan sinyal-sinyal tertentu terkait dengan kebijakan perusahaan. Informasi tersebut dapat digunakan oleh investor dalam merespon kinerja perusahaan yang selanjutnya tercermin dalam harga saham. Oleh karena itu, pengujian atas nilai perusahaan sektor perbankan perlu diinvestigasi lebih lanjut.

Pengujian terhadap nilai perusahaan telah dilakukan dalam penelitian sebelumnya di antaranya dengan instrumen derivatif (Firmansyah \& Purnama, 2020; Novianti \& Firmansyah, 2020), kepemilikan CEO (Firmansyah, Jadi, \& Sukarno, 2021), leverage (Bing \& Li, 2019), profitabilitas (Kusuma \& Priantinah, 2018; Mubyarto, 2020), tata kelola perusahaan (Firmansyah, Setiawan, et al., 2020; Firmansyah, Jadi, Febrian, et al., 2021; M. M. Putri et al., 2020), ukuran perusahaan (Bing \& Li, 2019), pengungkapan pihak berelasi (Dresti \& Putri, 2021) pengungkapan keberlanjutan atau tanggung jawab sosial perusahaan (Amalia et al., 2021; Aryanto \& Setyorini, 2019; Cho et al., 2019; Firmansyah, Febrian, et al., 2021; Gaol et al., 2021; Loh et al., 2017; Machmuddah et al., 2020; Nur et al., 2019).

Aktivitas perusahaan tidak terlepas dari dinamika bisnis yang terjadi di dunia saat ini, salah satunya terkait dengan isu keberlanjutan. Perusahaan sebagai salah satu pihak yang perlu bertanggung jawab dalam isu keberlanjutan perlu menerapkan keberlanjutan dalam aktivitas perusahaan. Aktivitas keberlanjutan atau tanggung jawab sosial perusahaan dapat disampaikan kepada publik melalui pengungkapan dari laporan yang disajikan oleh perusahaan. Pengungkapan keberlanjutan dapat meningkatkan fungsi laporan keuangan dalam perspektif investor karena investor mendapatkan informasi lain yang tidak terkait dengan keuangan secara langsung (Alexander \& Palupi, 2020). Beberapa informasi yang perlu diungkapkan dan disajikan oleh manajemen juga dapat dianggap sebagai sinyal bahwa perusahaan berada dalam kondisi yang kuat. Dalam konteks perusahaan sektor perbankan yang memiliki karakteristik yang tidak berinteraksi langsung dengan lingkungan, penerapan tanggung jawab sosial masih bersifat sukarela karena belum ada satupun regulasi yang mensyaratkan pelaporan keberlanjutan atau tanggung jawab sosial dalam arti yang luas. Pengujian yang dilakukan oleh 


\section{JURNALKU}

Volume 1 No. 4, Desember 2021

Cho et al. (2019), Loh et al. (2017), Machmuddah et al. (2020), Masruroh \& Makaryanawati (2020), Nur et al. (2019), Z. B. Putri \& Budiyanto (2018) menyimpulkan bahwa pengungkapan tanggung jawab sosial perusahaan atau pengungkapan keberlanjutan berpengaruh positif terhadap nilai perusahaan. Sementara itu, Amalia et al. (2021), Aryanto \& Setyorini (2019), Firmansyah, Febrian, et al. (2021), Gaol et al. (2021) menemukan bahwa pengungkapan tanggung jawab sosial atau pengungkapan keberlanjutan tidak berpengaruh terhadap nilai perusahaan. Oleh karena itu, pengujian pengungkapan keberlanjutan terhadap nilai perusahaan perlu dilakukan kembali.

Penelitian ini bertujuan untuk menginvestigasi pengungkapan keberlanjutan terhadap nilai perusahaan pada perusahaan sub sektor perbankan di Indonesia. Penelitian ini menggunakan indeks Global Reporting Initiative (GRI) 2018 untuk memproksikan pengungkapan keberlanjutan yang masih jarang dilakukan dalam penelitian sebelumnya. Masruroh \& Makaryanawati (2020) menggunakan indeks tanggung jawab sosial berdasarkan ISO26000. Cho et al. (2019) menggunakan indeks Korea Economic Justice Institute (KEJI) dalam mengukur pengungkapan keberlanjutan. Gaol et al. (2021), Machmuddah et al. (2020), dan Nur et al. (2019) menggunakan indeks GRI 4 untuk mengukur tanggung jawab sosial perusahaan. Firmansyah, Febrian, et al. (2021) menggunakan kinerja tanggung jawab sosial berdasarkan indeks GRI 4 yang disesuaikan dengan Lee (2017). GRI 2018 merupakan standar penerapan keberlanjutan yang digunakan secara global yang telah disesuaikan dengan kondisi terkini, sehingga penggunaan indeks pengungkapan keberlanjutan dengan menggunakan GRI 2018 dapat lebih relevan.

Penelitian ini diharapkan dapat menjadi literatur terkait dengan pengungkapan keberlanjutan yang dilakukan oleh perusahaan terkait dengan riset akuntansi keuangan berbasis pasar modal. Penelitian ini juga diharapkan dapat memberikan kontribusi dalam pengembangan kebijakan yang dilakukan oleh Otoritas Jasa Keuangan terkait dengan implementasi keberlanjutan oleh perusahaan sub sektor perbankan maupun perusahaan yang terdaftar di Bursa Efek Indonesia.

Penelitian ini menggunakan arus kas operasi dan rasio cepat sebagai variabel kontrol. Arus kas operasi dan rasio lancar perusahaan diharapkan dapat mendukung perusahaan dalam menerapkan keberlanjutan untuk dapat meningkatkan kepercayaan pasar. Kondisi arus kas operasi dan rasio lancar perusahaan dapat diakibatkan adanya kebijakan perusahaan. Volatilitas arus kas cenderung menurunkan persepsi investor terhadap nilai perusahaan karena ketidakstabilan kas untuk melakukan berbagai jenis aktivitas akan menurunkan minat investor terhadap perusahaan (Novianti \& Firmansyah, 2020), sehingga atas perubahan arus kas operasi yang tidak menentu tersebut justru akan membuat para investor enggan untuk menambah investasi di dalam suatu perusahaan. (Fajri \& Juanda, 2021) menemukan bahwa arus kas operasi dapat meningkatkan nilai perusahaan. Dengan demikian, jika arus kas dapat bertahan stabil atau selalu positif, kemungkinan besar para investor akan lebih bersedia menanamkan investasinya. Selanjutnya, Syamsuddin et al. (2021) menemukan bahwa tingkat likuiditas berpengaruh positif terhadap nilai perusahaan. Rasio cepat yang merupakan bagian dari tingkat likuiditas dengan nilai yang tinggi mengindikasikan bahwa perusahaan dapat memelihara aktivitas operasinya dalam rangka untuk mendapatkan aset-aset yang lebih likuid.

\section{KAJIAN PUSTAKA}

Teori pensinyalan menjelaskan hubungan antara manajemen internal yang berperan sebagai pemberi sinyal kepada pihak eksternal yang berperan sebagai penerima sinyal (Spence, 1973). Terkait dengan pasar saham, Morris (1987) menjelaskan bahwa terdapat asimetri informasi terjadi karena manajemen memiliki informasi perusahaan yang lebih banyak dibandingkan dengan ketersediaan informasi yang dimiliki investor. Investor akan menerima 


\section{JURNALKU}

Volume 1 No. 4, Desember 2021

dan menilai informasi berdasarkan informasi yang diberikan oleh manajemen. Salah satu informasi yang diberikan adalah informasi atas implementasi keberlanjutan yang dilakukan oleh perusahaan.

Cho et al. (2019), Loh et al. (2017), Machmuddah et al. (2020), Masruroh \& Makaryanawati (2020), Nur et al. (2019), Z. B. Putri \& Budiyanto (2018) menemukan bahwa pengungkapan tanggung jawab sosial perusahaan berpengaruh positif terhadap nilai perusahaan. Gitahi et al. (2018) menyimpulkan bahwa pengungkapan tanggung jawab sosial perusahaan berpengaruh positif terhadap harga pasar rata-rata per saham. Hasil pengujian tersebut tidak sejalan dengan Amalia et al. (2021), Aryanto \& Setyorini (2019), Firmansyah, Febrian, et al. (2021), dan Gaol et al. (2021).

Pengungkapan tanggung jawab sosial perusahaan mewakili pemenuhan bentuk tanggung jawab dan kepedulian perusahaan untuk memperbaiki ketimpangan sosial, ketimpangan ekonomi, dan kerusakan lingkungan yang dilakukan perusahaan. Tanggung jawab sosial perusahaan yang saat ini dikenal dengan keberlanjutan merupakan salah satu bentuk respon perusahaan terkait dengan isu keberlanjutan di dunia saat ini. Kebijakan tersebut dapat berdampak kepada aktivitas operasi perusahaan dengan mengubah proses bisnis perusahaan yang tidak mudah dan membutuhkan biaya yang cukup besar. Namun, implementasi keberlanjutan merupakan informasi yang berguna oleh investor terkait dengan respon perusahaan terhadap kondisi global saat ini. Oleh karena itu, pengungkapan aktivitas keberlanjutan yang dilakukan oleh perusahaan merupakan informasi yang dapat meningkatkan nilai perusahaan dan keberlangsungan perusahaan di masa mendatang.

$\mathrm{H}_{1}$ : Pengungkapan keberlanjutan berpengaruh positif terhadap nilai perusahaan

\section{METODE}

Penelitian ini menggunakan data sekunder perusahaan sub sektor perbankan yang terdaftar di Bursa Efek Indonesia. Data penelitianberupa laporan keuangan perusahaan, laporan tahunan, laporan keberlanjutan dan harga saham perusahaan yang diperoleh dari $\underline{w w w . i d x . c o . i d}, \underline{w w w . f i n a n c e . y a h o o . c o m}$, dan situs resmi perusahaan. Pengambilan sampel dilakukan teknik purposive sampling dengan kriteria sebagai berikut:

Tabel 1 Sampel Penelitian

\begin{tabular}{lll}
\hline No. & Keterangan & Jumlah \\
\hline 1 & Perusahaan sub sektor perbankan yang terdaftar di BEI posisi 1 Nov & 44 \\
& 2020 & Perusahaan \\
2 & $\begin{array}{l}\text { Perusahaan sub perbankan yang terdaftar di BEI setelah 1 Januari } \\
(2)\end{array}$ & $\begin{array}{l}\text { Perusahaan } \\
3\end{array}$ \\
2018 & $\begin{array}{l}\text { Perusahaan perbankan yang tidaj menyatakan kegiatan tanggung } \\
\text { jawab sosial dengan jelas pada laporan keuangan maupun laporan }\end{array}$ & Perusahaan \\
& $\begin{array}{l}\text { tahunannya untuk periode tersebut } \\
\text { Perusahaan yang dapat digunakan dalam penelitian ini }\end{array}$ & 30 \\
& $\begin{array}{l}\text { Jumlah Tahun } \\
\text { Total Sampel }\end{array}$ & Perusahaan \\
\end{tabular}

Sumber: data diolah

Variabel dependen dalam penelitian ini adalah nilai perusahaan dengan proksi Tobin's Q sebagaimana Cho et al. (2019), Firmansyah, Febrian, et al. (2021), dan Machmuddah et al. (2020).

$$
\text { Tobins }^{\prime} Q=\frac{\text { Nilai Pasar Saham Perusahaan }+ \text { Nilai Buku Total Liabilitas }}{\text { Nilai Buku Total Aset }}
$$




\section{JURNALKU}

Volume 1 No. 4, Desember 2021

Variabel independen yang digunakan dalam penelitian ini adalah tingkat pengungkapan keberlanjutan dengan menggunakan proksi indeks GRI 2018. Penggunaan proksi ini menyesuaikan dari proksi sebelumnya yang dilakukan oleh Firmansyah, Febrian, et al. (2021), Firmansyah \& Estutik (2020), Firmansyah \& Irwanto (2020), dan Widyansyah et al. (2021), dengan melakukan penyesuaian ke dalam GRI 2018 dan kualitas pengungkapan. GRI 2018 membagi kriteria keberlanjutan menjadi 3 poin utama. Pertama, perusahaan secara jelas mencantumkan aspek ekonomi ke dalam 6 kriteria utama. Kedua, perusahaan secara jelas mencantumkan aspek lingkungan ke dalam 7 kriteria utama. Ketiga, perusahaan secara jelas mencantumkan aspek sosial ke dalam 18 kriteria utama. Melalui pembagian kriteria tersebut, penelitian ini menggunakan penentuan skor mulai dari GRI indeks 201 sampai dengan GRI indeks 419 dengan skala skoring 0-3 yang rincian skoringnya adalah sebagai berikut:

Nilai 0 : Perusahaan tidak menyampaikan informasi apapun di dalam laporan.

Nilai 1 : Perusahaan menyampaikan informasi yang tidak jelas atau tidak lengkap, hanya menuliskan rencana tanpa realisasi dalam laporan, atau hanya mencantumkan penjelasan tidak melaksanakan kriteria keberlanjutan sesuai indeks tertentu.

Nilai 2 : Perusahaan telah menyampaikan informasi yang jelas dan lengkap terkait kriteria indeks, namun pengungkapannya saat ini belum ada pada subbagian pelaporan keberlanjutan (misplacement) pada laporan tahunan atau pengungkapan tidak pada laporan keberlanjutan.

Nilai 3 : Perusahaan telah menyampaikan informasi yang jelas dan lengkap terkait kriteria indeks pada subbagian pelaporan keberlanjutan dalam laporan tahunan atau pengungkapan yang sudah ada dalam laporan keberlanjutan.

Pengungkapan keberlanjutan yang digunakan dalam penelitian ini menggunakan proksi sebagai berikut:

Di mana:

$$
\text { Sustain }=\frac{\sum \text { Sustainability }}{\sum \text { GRI } 2018}
$$

Sustain : indeks CSR oleh perusahaan i pada tahun $\mathrm{t}$

$\Sigma$ Sustainability: total bobot komponen yang diungkapkan oleh perusahaan dalam periode $\mathrm{t}$

$\Sigma$ GRI 2018 : total bobot komponen yang harus diungkapkan perusahaan berdasarkan GRI 2018

Variabel kontrol dalam penelitian ini menggunakan arus kas operasi dan rasio lancar. Proksi arus kas operasi mengikuti Altuntas et al. (2017) sebagai berikut:

$$
\text { OCF }=\frac{\Sigma \text { Arus Kas Operasi }}{\text { Nilai Total Aset }}
$$

Rasio cepat menggunakan proksi sebagaimana Ismanandar (2016) sebagai berikut:

$$
\text { QUICK }=\frac{\text { (Aset Lancar }- \text { Persediaan) }}{\text { Kewajiban Lancar }}
$$

Uji hipotesis dilakukan dengan menggunakan analisis regresi linier berganda dengan data panel. Untuk menentukan model terbaik dilakukan pemilihan model dengan menggunakan common effect model, fixed effect model dan random effect model. Adapun model penelitian ini adalah sebagai berikut:

Di mana:

$$
\text { TOBINSQ }_{\text {it }}=\beta 0+\beta 1 \text { Sustain }_{i t}+\beta 20 C F_{i t}+\beta 3 Q_{\text {UICK }}+\varepsilon_{i t}
$$

TOBINSQ $_{\text {it }} \quad$ : nilai Tobin's Q perusahaan i periode t

Sustain $_{\text {it }} \quad$ : pengungkapan keberlanjutan perusahaan i periode $\mathrm{t}$

$\mathrm{OCF}_{\text {it }} \quad$ : arus kas operasi perusahaan i periode $\mathrm{t}$

QUICK $_{\text {it }}$ : rasio cepat perusahaan i periode $\mathrm{t}$ 


\section{JURNALKU}

Volume 1 No. 4, Desember 2021

\section{HASIL DAN PEMBAHASAN}

Berdasarkan data yang diperoleh dari laporan keuangan dan laporan berkelanjutan perusahaan bank yang dipilih menjadi sampel penelitian, hasil pengolahan data terkait statistik deskriptif terdapat pada Tabel 2.

Tabel 2 Statistik Deskriptif

\begin{tabular}{lrrrr}
\hline \multicolumn{1}{c}{ Uraian } & TOBINSQ & SUST & \multicolumn{1}{c}{ OCF } & QUICK \\
\hline Mean & 1.0987 & 0.3607 & -0.0124 & 0.7658 \\
Median & 1.0021 & 0.3333 & -0.0030 & 0.6989 \\
Std Dev. & 0.2588 & 0.1322 & 0.0699 & 0.3056 \\
Min. & 0.7862 & 0.1505 & -0.1598 & 0.0995 \\
Max. & 2.2869 & 0.6667 & 0.1503 & 1.4438 \\
Obs. & 60 & 60 & 60 & 60 \\
\hline
\end{tabular}

Sumber: data diolah

Selanjutnya ringkasan hasil uji hipotesis dengan menggunakan fixed effect model adalah sebagai berikut:

Tabel 3 Hasil Uji Model Regresi

\begin{tabular}{crrr}
\hline Variable & \multicolumn{1}{c}{ Coeff. } & \multicolumn{1}{c}{ t-Stat. } & \multicolumn{1}{l}{ Prob. } \\
\hline C & 0.944 & 26.111 & $0.000 * * *$ \\
CSR & 0.316 & 3.558 & $0.001 * * *$ \\
CFLOW & 0.256 & 12.973 & $0.000 * * *$ \\
QRATIO & 0.058 & 9.373 & $0.000 * * *$ \\
R $^{2}$ & 0.997 & & \\
Adj. R & 0.993 & & \\
F-Stat & 265.088 & & \\
Prob(F-statistic) & 0.000 & & \\
\hline
\end{tabular}

Sumber: data diolah

Hasil pengujian menunjukkan bahwa pengungkapan keberlanjutan berpengaruh positif terhadap nilai perusahaan. Hasil pengujian sejalan dengan Cho et al. (2019), Loh et al. (2017), Machmuddah et al. (2020), Masruroh \& Makaryanawati (2020), Nur et al. (2019), Z. B. Putri \& Budiyanto (2018). Namun, penelitian ini tidak sejalan dengan Amalia et al. (2021), Aryanto \& Setyorini (2019), Firmansyah, Febrian, et al. (2021), Gaol et al. (2021). Hasil pengujian dalam penelitian ini menunjukkan bahwa adanya peningkatan pemahaman investor di Indonesia terkait dengan pengungkapan keberlanjutan yang diterapkan oleh perusahaan perbankan. Selain itu, penelitian ini mengindikasikan bahwa pengungkapan dengan menggunakan GRI 2018 lebih mudah dipahami oleh investor. Hasil penelitian ini berbeda dengan Gaol et al. (2021) yang menggunakan data perusahaan sub sektor perbankan di Indonesia dengan indeks keberlanjutan GRI4. Penggunaan proksi nilai perusahaan yang berbeda oleh Gaol et al. (2021) yaitu price to book value, merupakan salah satu faktor perbedaan hasil pengujian penelitian tersebut dengan penelitian ini.

Berdasarkan statistik deskriptif pengungkapan keberlanjutan masih cukup rendah dengan nilai dengan nilai rata-rata 0.36075 sebesar minimum sebesar 0.1505 dan nilai maksimum sebesar 0.6667. Informasi yang disajikan dapat meningkatkan respon positif investor karena investor untuk perusahaan perbankan diduga memiliki kepedulian atas pengungkapan keberlanjutan yang dilakukan oleh perusahaan sub sektor perbankan. Berdasarkan teori pensinyalan, investor dan calon investor akan merespon positif apabila 


\section{JURNALKU}

Volume 1 No. 4, Desember 2021

terdapat good news, sehingga informasi pengungkapan keberlanjutan merupakan good news bagi investor dan calon investor.

Penerapan keberlanjutan yang merupakan bentuk tanggung jawab sosial perusahaan dalam mengungkapan informasi perusahaan yang lebih transparan kepada publik khususnya kepada investor. Informasi pengungkapan keberlanjutan merupakan indikasi bahwa perusahaan dapat menjalankan etika yang baik dalam bisnis operasi perusahaan. Selain itu, informasi pengungkapan keberlanjutan dapat mendorong untuk meminimalisir informasi asimetri antara manajer selaku penyelenggara perusahaan dan investor atau pemegang saham selaku pemilik perusahaan. Isu keberlanjutan merupakan isu global yang dinamis termasuk informasi yang diterima oleh investor. Dengan demikian, perusahaan yang telah mengimplementasikan aktivitas keberlanjutan dalam operasi perusahaan akan mendapat respon positif dari investor dan calon investor.

\section{PENUTUP}

\section{Simpulan}

Pengungkapan keberlanjutan dapat meningkatkan nilai perusahaan karena dapat meningkatkan respon positif bagi investor. Investor menganggap bahwa pengungkapan keberlanjutan oleh perusahaan merupakan respon perusahaan terhadap isu global saat ini dan indikasi meningkatnya transparansi informasi kepada publik.

\section{Saran}

Penelitian ini masih memiliki keterbatasan dalam hal subyektifitas atas penilaian indeks GRI 2018 dan penggunaan perusahaan sub sektor perbankan hanya untuk perusahaan yang terdaftar di Bursa Efek Indonesia. Selain itu, penelitian ini hanya menggunakan periode 2 tahun. Penelitian selanjutnya dapat menggunakan periode waktu yang lebih panjang dan dapat menggunakan data perusahaan dengan sektor yang lebih luas untuk mendapatkan hasil penelitian yang lebih baik. Penelitian ini menunjukkan bahwa Otoritas Jasa Keuangan perlu meningkatkan kebijakan dalam penerapan keberlanjutan oleh perusahaan sub sektor perbankan dan perusahaan sektor lainnya yang terdaftar di Bursa Efek Indonesia. Selain itu, Otoritas Jasa Keuangan perlu melakukan pengawasan atas implementasi keberlanjutan yang dilakukan oleh perusahaan sub sektor perbankan di Indonesia.

\section{DAFTAR PUSTAKA}

Alexander, N., \& Palupi, A. (2020). Pengaruh corporate social responsibility reporting terhadap manajemen laba. Jurnal Bisnis Dan Akuntansi, 22(1), 105-112. https://doi.org/10.34208/jba.v22i1.628

Altuntas, M., Liebenberg, A. P., Watson, E. D., \& Yildiz, S. (2017). Hedging, cash flows, and firm value: evidence of an indirect effect. Journal of Insurance Issues, 40(1), 1-22. https://www.jstor.org/stable/44160924

Amalia, A. R., Rahmawati, F., Amalia, S. L. R., \& Sugiyanto, S. (2021). Pengaruh sustainability reporting terhadap nilai perusahaan dengan kinerja keuangan sebagai variabel moderating. Humanities, Management, and Science Proceeding, 1(2), 130-140. http://openjournal.unpam.ac.id/index.php/SNH/article/view/11212

Aryanto, A., \& Setyorini, C. T. (2019). Pengaruh tata kelola perusahaan dan tanggung jawab sosial terhadap nilai perusahaan sektor pertambangan. Jurnal Informasi, Perpajakan, Akuntansi, Dan Keuangan Publik, 14(2), 181. https://doi.org/10.25105/jipak.v14i2.5020

Bing, T., \& Li, M. (2019). Does CSR signal the firm value? Evidence from China. Sustainability, 11(15), 1-22. https://doi.org/10.3390/su11154255

Cho, S. J., Chung, C. Y., \& Young, J. (2019). Study on the relationship between CSR and financial performance. Sustainability, 11(2), 1-26. https://doi.org/10.3390/su11020343 
Dresti, A., \& Putri, F. D. (2021). Analisis perbandingan pengaruh pengungkapan dan transaksi pihak berelasi terhadap nilai perusahaan pada sektor properti. Jurnalku, 1(2), 70-84. https://jurnalku.org/index.php/jurnalku/article/view/17

Fajri, F., \& Juanda, J. (2021). Pengaruh arus kas operasi, investasi, dan pendanaan terhadap nilai perusahaan pada sektor keuangan di Indonesia. Jurnal Ilmiah Mahasiswa Ekonomi Manajemen, 6(3), 486-489. https://doi.org/10.24815/jimen.v6i3.17052

Firmansyah, A., \& Estutik, R. S. (2020). Environmental responsibility performance, corporate social responsibility disclosure, tax aggressiveness: Does corporate governance have a role? Journal of Governance and Regulation, 9(4), 8-24. https://doi.org/10.22495/jgrv9i4art1

Firmansyah, A., Febrian, W., Jadi, P. H., Husna, M. K., \& Putri, M. A. (2021). Respon investor atas tanggung jawab sosial tata kelola perusahaan di Indonesia: perspektif resource based view. E-Jurnal Akuntansi, $31(8), \quad 1918-1935$. https://doi.org/10.24843/EJA.2021.v31.i08.p04

Firmansyah, A., \& Irwanto, A. (2020). Do Income Smoothing, Forward-Looking Disclosure, And Corporate Social Responsibility Decrease Information Uncertainty? International Journal of Psychosocial Rehabilitation, 24(07), 9513-9525. https://doi.org/10.37200/IJPR/V24I7/PR270955

Firmansyah, A., Jadi, P. H., Febrian, W., \& Sismanyudi, D. (2021). Pengaruh tata kelola perusahaan dan ukuran perusahaan terhadap pengungkapan emisi karbon di Indonesia. 16(2), 303-320. https://doi.org/10.25105/jipak.v16i2.9420

Firmansyah, A., Jadi, P. H., \& Sukarno, R. S. (2021). Bagaimana respon investor terhadap kepemilikan saham oleh CEO? Jurnal Online Insan Akuntan, 4(1), 15-28. https://ejournalbinainsani.ac.id/index.php/JOIA/article/view/1476

Firmansyah, A., \& Purnama, E. B. D. (2020). Do derivatives instruments ownership decrease firm value in Indonesia? Riset Akuntansi Dan Keuangan Indonesia, 5(1), 1-9. https://doi.org/10.23917/reaksi.v5i1.9817

Firmansyah, A., Setiawan, T. A., \& Fathurahman, F. (2020). Nilai perusahaan: kebijakan utang, good corporate governance, cash holding. Jurnal Akuntansi Dan Bisnis, 20(2), 237. https://doi.org/10.20961/jab.v20i2.568

Firmansyah, A., Sihombing, P., \& Kusumastuti, S. Y. (2020). The determinants of idiosyncratic volatility in Indonesia banking industries. Jurnal Keuangan Dan Perbankan, 24(2), 175188. https://doi.org/10.26905/jkdp.v24i2.3851

Gaol, G. A. L., Firmansyah, A., \& Irawati, A. D. (2021). Intellectual capital, corporate social responsibility, and firm value in Indonesia's banking industries. Jurnal Riset Akuntansi Terpadu, 14(1), 76-87. https://doi.org/110.35448/jrat.v14i1.10229

Gitahi, J., Nasieku, T., \& Memba, F. (2018). Corporate social responsibility disclosure and the value relevance of annual reports for listed banks in Kenya. European Scientific Journal, 14(4), 329-349. https://doi.org/10.19044/esj.2018.v14n4p329

Investindo. (n.d.). Keuntungan berinvestasi di Indonesia bagi investor Asing. https://www.investindonesia.go.id/id/artikel-investasi/detail/keuntungan-berinvestasi-diindonesia-bagi-investor-asing

Ismanandar, M. (2016). Pengaruh current ratio, quick ratio dan cash ratio terhadap pembiayaan produktif bank syariah. Inklusif: Jurnal Pengkajian Penelitian Ekonomi Dan Hukum Islam, 1(2), 23-32. https://doi.org/10.24235/inklusif.v1i2.1828

Katadata. (2017). Penetrasi layanan perbankan Indonesia tertinggal dari Malaysia. https://databoks.katadata.co.id/datapublish/2017/10/11/penetrasi-layanan-perbankanindonesia-tertinggal-darimalaysia

Kemenperin. (2020). Indonesia berpotensi lahirkan banyak global brand. Kemenperin. 
https://kemenperin.go.id/artikel/21981/Indonesia-Berpotensi-Lahirkan-Banyak-GlobalBrand

Kieso, D. E., Weygandt, J. J., \& Warfield, T. D. (2018). Intermediate Accounting: IFRS Edition, 3rd Edition. John Wiley \& https://www.google.co.id/books/edition/Intermediate_Accounting/VXH5twEACAAJ?hl $=$ en

Kusuma, A. W., \& Priantinah, D. (2018). Pengaruh pengungkapan sustainability report dan ukuran perusahaan terhadap nilai perusahaan dengan profitabilitas sebagai variabel pemoderasi pada perusahaan yang bergabung di ISSI dan Konvensional periode 20142016. Jurnal Nominal, 7(2), 91-105. https://doi.org/10.21831/nominal.v7i2.21352

Lee, K. H. (2017). Does size matter? evaluating corporate environmental disclosure in the Australian mining and metal industry: a combined approach of quantity and quality measurement. Business Strategy and the Environment, 26(2), 209-223. https://doi.org/10.1002/bse.1910

Loh, L., Thomas, T., \& Wang, Y. (2017). Sustainability reporting and firm value: Evidence from Singapore-listed companies. Sustainability, 9(11), 1-12. https://doi.org/10.3390/su9112112

Machmuddah, Z., Sari, D. W., \& Utomo, S. D. (2020). Corporate social responsibility, profitability and firm value: Evidence from Indonesia. Journal of Asian Finance, $\begin{array}{llll}\text { Economics } & \text { Bnd }\end{array}$ https://doi.org/10.13106/JAFEB.2020.VOL7.NO9.631

Masruroh, A., \& Makaryanawati, M. (2020). Pengaruh penggungkapan tanggung jawab sosial terhadap nilai perusahaan pada perusahaan pertambangan yang terdaftar di bursa efek. Jurnal Akuntansi Aktual, 7(1), 57-66. https://doi.org/10.17977/um004v7i12020p67

Morris, R. D. (1987). Signalling, agency theory and accounting policy choice. Accounting and Business Research, 18(69), 47-56. https://doi.org/10.1080/00014788.1987.9729347

Mubyarto, N. (2020). The influence of profitability on firm value with capital structure as the $\begin{array}{llll}\text { mediator. } & \text { Eournal 184-199. }\end{array}$ https://doi.org/10.21831/economia.v16i2.30405

Novianti, T., \& Firmansyah, A. (2020). The effect of tax risk, hedging, income smoothing, and cash flows volatility on firm value. Test Engineering and Management, 83(April), 96759686. https://www.testmagzine.biz/index.php/testmagzine/article/view/5362

Nur, F., Saraswati, E., \& Andayani, W. (2019). Determinan pengungkapan tanggung jawab sosial perusahaan dan nilai perusahaan: kasus Indonesia. Jurnal Dinamika Akuntansi Dan Bisnis, 6(2), 213-228. https://doi.org/10.24815/jdab.v6i2.14087

Putri, M. M., Firmansyah, A., \& Labadia, D. (2020). Corporate social responsibility disclosure, good corporate governance, firm value: evidence from Indonesia's food and beverage companies. The Accounting Journal of Binaniaga, 5(2), 113. https://doi.org/10.33062/ajb.v5i2.398

Putri, Z. B., \& Budiyanto, B. (2018). Pengaruh corporate social responsibility terhadap nilai perusahaan dengan kepemilikan manajerial sebagai variabel moderating. Jurnal Ilmu Dan Riset Manajemen, 7(3), 1-16. http://jurnalmahasiswa.stiesia.ac.id/index.php/jirm/article/view/1124

Spence, M. (1973). Job market signaling. The Quarterly Journal of Economics, 87(3), 355373. https://doi.org/10.2307/1882010

Syamsuddin, F. R., Mas'ud, M., \& Wahid, M. (2021). Effect of solvency, profitability, and liquidity on company value (study of property and real estate companies listed on the Indonesia stock exchange for the period 2015-2018). Profitability: Jurnal Ilmu Manajemen, $5(1)$ 98-136. 


\section{JURNALKU}

Volume 1 No. 4, Desember 2021

https://journal.unismuh.ac.id/index.php/profitability/article/view/4859

Widyansyah, A. S., Firmansyah, A., Prakosa, D. K., \& Geno, M. R. P. (2021). Risk relevance of comprehensive income in Indonesia: the role of corporate social responsibility, good corporate governance, tax avoidance. International Business and Accounting Research Journal, 5(2), 118-133. https://doi.org/10.35474/ibarj.v5i2.185 